STOCKHOLDING:

Participation, Location, AND Spillovers

Dimitris Christelis, Dimitris Georgarakos, Michael Haliassos 


\title{
Stockholding: \\ Participation, Location, and Spillovers ${ }^{1}$
}

\author{
Dimitris Christelis \\ University of Padua, University of Venice “ca' Foscari”, CSEF, and CFS \\ Dimitris Georgarakos \\ Goethe University Frankfurt and CFS \\ Michael Haliassos \\ Goethe University Frankfurt, CFS, MEA and CEPR
}

October 18, 2010

\begin{abstract}
This paper provides the first joint analysis of household stockholding participation, location among stockholding modes, and participation spillovers. Our model matches observed participation, conditional and unconditional, and asset location patterns. We find that financial sophistication correlates strongly only with direct stockholding and mutual fund participation, while social interactions mainly influence stockholding through retirement accounts. Whether retirement account owners include7 stocks in them strongly depends on owner characteristics, unlike with mutual fund owners and investment in stock funds. Stockholding is more common among retirement account owners, but mainly because of owner characteristics rather than spillovers from retirement account ownership.
\end{abstract}

JEL Classification Codes: G11, E21, D14, C35.

Keywords: Stockholding, asset location, retirement accounts, household finance, multivariate probit, simulated maximum likelihood.

\footnotetext{
${ }^{1}$ We are grateful to Sumit Aggarwal, Luca Benzoni, Eric French, James Poterba, Tullio Jappelli, an anonymous referee and the Editor for helpful comments and suggestions. We would also like to thank participants in the seminar series at the Federal Reserve Bank of Chicago, in the 3d CSEF-IGIER conference, and in the 2009 SAET conference for their comments. Research on this paper has been supported by the German Research Foundation (Deutsche Forschungsgemeinschaft - DFG) under the grant 'Regulating Retail Finance'; and by the Center for Financial Studies under its program on Household Wealth Management. Contact information: Christelis: dimitris.christelis@gmail.com; Georgarakos:Georgarakos@wiwi.uni-frankfurt.de; Haliassos: Haliassos@wiwi.uni-frankfurt.de.
} 


\section{Introduction}

In the past two decades, the US and major European countries have witnessed an expanded range of financial products, such as mutual funds and retirement accounts, and a significant increase in household financial risk taking. Increasing ratios of retirees to workers, resulting from the ageing of the population, challenge the ability of social security systems to provide adequate pension levels and make it imperative for households to take advantage of asset accumulation opportunities during their working life. Stocks have gained increasing importance in household portfolios, mainly because of their wealth generating potential over longer investment horizons. ${ }^{1}$ As a result of financial innovation and policy incentives, individuals can now invest in stocks directly, through shares in mutual funds involving stocks, as well as through defined contribution pension plans and individual retirement accounts. Proliferation of financial instruments has enhanced the ability of fully informed and financially sophisticated households to accumulate wealth for retirement. On the other hand, it may have also introduced asymmetric hurdles for the less sophisticated, less wealthy or more risk averse, who now need to make active portfolio choices instead of relying on social security benefits provided to them through a pension formula.

As documented below, observed household portfolios are very heterogeneous in terms of the list of included assets, in contrast to the implications of simple 'two-fund separation' theorems derived in textbook models of asset pricing. Overall stock market participation is limited to about half of the population in the US; much fewer households own stocks directly or through mutual funds. Stockholders choose various combinations of stockholding modes, i.e., they favor different patterns of stock location. Households who own retirement accounts in order to meet the financial challenges of old age exhibit higher stockholding participation rates than the population at large. It is unclear, however, if such stock market participation is due to retirement account ownership per se (e.g. because it confers some knowledge about 
investing in stocks) or rather to their own characteristics that are generally conducive to stockholding.

In this new environment, at least three important questions arise: Who is more likely to take advantage of the various available stockholding opportunities? Given stock ownership in any form, what determines the choice of investment vehicles through which stocks are held (e.g. mutual funds)? Finally, given the widespread use of defined-contribution pension plans and retirement accounts in the US, does ownership of such accounts make stockholding outside them (in the form of direct holdings or stock mutual funds) also more likely?

Up to now, analysis of these three questions, i.e. participation, location, and spillovers, has been performed separately. The participation literature has attributed limited household participation in the stock market mainly to fixed entry/participation costs. ${ }^{2}$ Possible factors that account for limited participation among well-to-do households (for whom such costs would not be a deterrent) include asset ignorance (Guiso and Jappelli, 2005), lack of trust (Guiso, Zingales and Sapienza, 2008), social interactions (Hong, Kubik and Stein, 2004), cognitive difficulties (Christelis, Jappelli and Padula, 2010), and lack of financial literacy (Van Rooij, Alessie, and Lusardi, 2007).

The importance of asset location has been stressed by Bergstresser and Poterba (2002) and Garlappi and Huang (2006), who put emphasis on tax considerations by studying possible violations of optimal stock placement between taxable (such as directly held stocks and mutual funds) and tax-deferred vehicles (retirement accounts).

Asset participation spillovers have not been extensively studied up to now, but are starting to receive attention in view of population aging and increased ownership of retirement accounts. An important research and policy question is whether ownership of retirement accounts, which is induced by the need to finance retirement, will also promote other forms of stockholding. Retirement accounts are regarded as the main factor behind the spread of stockholding in the US. A 2005 report by the Investment Company Institute and Securities 
Industry Association stresses the role of defined contribution pension plans, especially 401(k)s in this context. ${ }^{3}$ A positive view of their role in promoting direct stockholding in Sweden among households that made an active fund choice, decided to hold equity, or to hold more funds within the public pension scheme special to Sweden, is provided by Karlsson, Massa, and Simonov (2007). On the other hand, Cardak and Wilkins (2009) argue that the introduction of mandatory contributions into employer based pension funds in Australia has not reduced or otherwise influenced direct stockholding.

To the best of our knowledge, the current paper represents the first integrated econometric analysis of all three issues in the context of a unified model that distinguishes between different stockholding choices and allows for interrelationships among observable and unobservable factors influencing stockholding choices.

There is good reason to distinguish among investments in different stockholding modes, because their risk properties, management requirements, and liquidity characteristics, are quite different. Direct stockholding is very risky (due to limited diversification), managementintensive, and fairly liquid. Mutual funds are quite liquid, but tend to be well-diversified and professionally rather than individually managed. Retirement accounts are typically taxdeferred, well diversified, though quite illiquid.

Participation costs also differ across these modes. Directly held stocks are subject to brokerage fees, and require both constant monitoring of the market and considerable information about firm characteristics. Mutual funds also have fees, and require performance monitoring, and complex choices among numerous alternative funds. On the other hand, they delegate responsibility for asset allocation to professionals. Finally, while investment in retirement accounts is tax deferred, investment in stocks directly and through mutual funds is on an after tax basis, and dividends and capital gains are taxable.

In view of these fundamental differences in properties of different stockholding vehicles, there is no a priori reason to think that they are equally likely to be chosen by 
households of given characteristics, observable or unobservable. We differentiate between stockholding vehicles, allowing for different roles of characteristics in each choice, and for correlations of unobserved factors influencing the different choices. Our approach is supported by differences in estimated patterns of influence of household characteristics on the different choices, economically and statistically significant estimates of correlations among unobservables, and by predicted participation rates that closely match the observed ones, whether unconditional or conditional.

We find sizeable effects of educational attainment, financial sophistication, and financial information acquired by working in the financial sector on both direct stockholding and ownership of mutual funds. Such effects support the view that mutual fund investment is not much simpler than participation in directly held stocks. Participation in retirement accounts, rather than being easily accessible to all, still depends heavily on factors such as educational attainment, race, willingness to take risks, and working in the financial sector. Social interactions turn out to be important for participation in retirement accounts, the widely held asset, but not for mutual funds or directly held stocks that are much more narrowly held. Among stockholders, we find significant gender effects on where stocks are located, with women preferring mutual funds and men direct holdings of stocks, controlling for remaining characteristics.

Given the popularity of retirement accounts and the financial information US households acquire through such ownership, should we expect them to be more likely to take up direct stockholding or stock mutual funds? In the data, we do find that retirement account owners are more likely to invest in other forms of stockholding than the general population. Our model allows us to examine whether this tendency is due to the characteristics that led them to own retirement accounts in the first place or to any informational spillovers from retirement account ownership. Our estimates do not suggest the presence of significant spillovers in this direction. 
The rest of the paper is organized as follows. Section 2 presents descriptive statistics on participation in the different stockholding modes and on asset location among stockholders. Section 3 presents the estimation model. Section 4 presents econometric results on participation in direct stockholding, mutual funds, retirement accounts, and in stockholding through mutual funds and retirement accounts. Section 5 presents our findings concerning asset location. Section 6 discusses asset participation spillovers, while Section 7 offers concluding remarks.

\section{Stockholding Modes in the Data}

We use data from four waves $(1995,1998,2001$, and 2004) of the Survey of Consumer Finances (SCF), which is the only US survey that is representative of the whole population and provides detailed information on all three possible stockholding modes as well as on investors' characteristics, attitudes and practices. ${ }^{4}$ Two additional features of the SCF are that the data are not subject to top coding of wealthy households; and that the rich, who own the largest share of wealth and are difficult to interview, are oversampled. Details on the survey design are provided in Kennickell (2000). In our analysis, we employ weights provided by the survey in order to make sample statistics representative for the whole population. Information on asset definitions and the construction of our variables can be found in Technical Appendix RAIII, available from the authors on request. The dates chosen encompass the peak of the stock market upswing of the middle and late nineties, the immediate aftermath of the stock market drop in 2000, and part of the subsequent market recovery.

Table 1 presents ownership rates in the data. Slightly more than half of households have retirement accounts, and more than three quarters of retirement account holders hold stocks in them. Stockholding through retirement accounts is the most widespread mode of stockholding, chosen by about $38 \%$ of the population (twice as much as direct stockholding). Approximately $15 \%$ of households invest in stock mutual funds. 
Looking at trends over our sample period, stockholding participation in general rose above the $50 \%$ mark in 2001 , but then fell below it by 2004 ; this development is also reflected in each of the stockholding modes. Among mutual fund owners, however, the share of those investing in stock mutual funds has slightly increased since 1998. Participation in the other two modes was higher in 2004 than in 1998, but the popularity of stocks fell among retirement account holders in 2004.

Table 2 refers to stock location, i.e., the use of the three (not mutually exclusive) stockholding options by stockholders. Approximately $80 \%$ of them have stocks in retirement accounts, which is by far the most popular location choice. About half as many stockholders invest in stocks directly, while under one third own stock mutual funds. The popularity of stock retirement accounts seems to have risen and then fallen over the period, as did that of stock mutual funds. However, direct stockholding kept rising throughout the period among those who owned stocks in any form.

Table 3 provides additional information on stock location by reporting the distribution of stockholders among all possible combinations of stockholding modes. By far the most popular choice of stockholders is to hold stocks only in their retirement accounts (more than $40 \%$ of stockholders in all years). A distant but clear second is the combination of stocks in retirement accounts with direct stockholding. Use of all three modes is observed among slightly more than $10 \%$ of households. Interestingly, while percentages differ across years somewhat, the ranking of these options has remained the same for households in the stock market, despite dramatic market swings. ${ }^{5}$

It is also instructive to contrast the distribution of demographic and economic characteristics of stockholders to that in the general population (shown in Table 4). Stockholding in any of the three modes, including the most common one, is undertaken by households quite different from the general population. Specifically, stockholders are more likely to be in a couple, college graduates, white, managers, and in better health, and less 
likely to be unemployed. In terms of financial attitudes and practices, they are much more likely than the general population to assume a higher than average financial risk and to consider leaving a bequest. Finally, stockholders tend to be far richer in terms of noninvestment income and real and financial wealth, to be subject to a higher federal marginal tax rate and less likely to be credit constrained. Stockholders are more likely to work (or to have worked) in the financial sector, and less likely to work in an industry that exhibits high income risk. ${ }^{6}$ All in all, the data in this Section make it clear that the subsample of stockholders is substantially different in many important demographic and economic characteristics from the rest of the population.

To summarize, we observe that, while participation rates in mutual funds and retirement accounts differ, the vast majority of fund holders and account owners include stocks in them. As our econometric results will show, however, this similarity in observed patterns conceals important differences across mutual funds and retirement accounts. Participation in mutual funds paves the way for inclusion of stocks in them almost regardless of household characteristics, while such characteristics are important for determining which subset of retirement account owners includes stocks in them. As for asset location, our finding that roughly 9 out of 10 stockholders do not use all three stockholding modes points to the importance of understanding what lies behind asset location choices among stockholders.

\section{The Model}

\subsection{Description}

We build a model of household stock investment that features the decision process shown in Fig. 1. Households face three (not mutually exclusive) investment choices: direct stockholding and investment in mutual funds and retirement accounts. If any of the latter two saving vehicles is chosen, then the household has to further decide whether to invest in stocks through them. This decision tree reflects observed participation patterns in the SCF, where 
holders of stock mutual funds are a subset of mutual fund owners, and the same is true for retirement accounts.

As pointed out, for instance, by Greene (1998), it is important for estimation to take into account the censoring in the data created by the fact that we do not observe stock investment in mutual funds (retirement accounts) for those households that do not own any mutual funds (retirement accounts). ${ }^{7}$ This goes beyond the logical necessity of having the broader instrument (e.g., mutual funds) in order to have the narrower instrument (e.g. stock mutual funds). Even in the absence of such logical necessity, a randomly drawn holder of, say, mutual funds would be more likely to own stock mutual funds than a household with similar characteristics chosen randomly from the whole population (comprising mutual fund owners and non-owners). This difference is due to the fact that, for any given configuration of observable characteristics, mutual fund owners have not only shown themselves to be willing to hold mutual funds in general, but they may have also acquired in the process specific information that facilitates ownership of stock mutual funds. As a result, a model that ignores the censoring issue and estimates the equation for stock investment in mutual funds on the whole sample can produce downward biased estimates of the probability to invest in stock mutual funds conditional on mutual fund ownership. To put it another way, ignoring the censoring problem is akin to estimating a wage equation on the whole population, which includes not only those employed but also the unemployed and those out of the labor force.

A key aspect of our model is that it allows for separate hurdles to be cleared for participating in each stockholding mode, and for potentially different contributions of each household characteristic or attitude to overcoming such hurdles. We further allow for all possible pair-wise correlations among the unobservables of each investment decision. Such correlations among investment decisions can arise because of factors common to all of them, such as an understanding of stockholding risks, common monitoring costs, and appreciation of the benefits of diversification (see Alessie, Hochguertel and van Soest, 2004). 
Our model could in principle be extended to include other household asset choices, e.g. housing, that might have unobservables correlated with those of stocks. Although this could be a worthwhile extension for future research, we chose not to go beyond the already involved task of integrating the three issues in this paper. First, adding a sixth or more equations makes our model even harder to estimate. Second, the considerable additional computational burden would not affect consistency of our estimates, but only potentially increase their efficiency, if unobservables are indeed correlated. As in a standard multivariate probit model, an added equation does not affect consistency but only efficiency.

Participation in mutual funds and retirement accounts is of interest in itself, but also as a first stage to the associated stockholding modes. The second stage decision may or may not be challenging, after the asset corresponding to the first stage has been chosen. For example, once somebody finds out about the nature, purpose, and rules of retirement accounts, the role and usefulness of stocks in these accounts may be quite clear. We would not, then, expect characteristics that show financial sophistication or willingness to assume higher risks to have significant further roles in determining inclusion of stocks, conditional on having opened the retirement account.

Our multivariate probit model with selection integrates participation analysis with asset location. The latter refers to the choice of a given mode conditional on the household holding stocks in any form, while allowing for all possible correlations across different choices. We discuss results on location in Section 5. The issue of participation spillovers from retirement account ownership to other stockholding modes is discussed in Section 6.

\subsection{Econometric Specification}

This Section outlines econometric issues arising in the estimation of our model. A fuller treatment of these issues appears in Technical Appendix RA.I, available from the authors on request. The household decision process discussed above implies an empirical model that 
consists of a tri-variate probit with two further probit equations estimated on the censored samples of mutual fund and retirement account owners. The use of probit models adjusted for selectivity was pioneered by Van de Ven and Van Praag (1981). Another recent example of such models, in a different context from ours, is provided by Jenkins, Capellari, Lynn, Jäckel and Sala (2006), who use a bivariate probit specification with selection to study consent to give information during a survey interview. ${ }^{8}$

In Table 5, the three first-stage equations (1), (2), and (4) model, respectively, the decisions to hold stocks directly, to hold any kind of mutual funds, and to have a retirement account. The two probit selection equations, (3) and (5), model the decisions to hold stock mutual funds given ownership of any mutual fund and to have a stock retirement account given ownership of a retirement account. We allow for unrestricted correlations between error terms of the five underlying latent indices. ${ }^{9}$

Table 4 shows summary statistics of our conditioning variables that have been found in the literature to be good predictors of stockholding (for examples that use the SCF see Bertaut and Starr-McCluer, 2001; Shum and Faig, 2006; Bilias, Georgarakos and Haliassos, 2010). ${ }^{10}$ A full set of variable definitions is included in the Technical Appendix RA.II. An important addition is the usually omitted federal marginal tax rate. We construct our sample by pooling the data from the 1995, 1998, 2001 and 2004 SCF waves $\left(17,565\right.$ households). ${ }^{11}$ In our specification, we follow the common practice in the participation literature of assuming zero cohort effects and including time dummies. ${ }^{12}$

Regression coefficients may give a misleading picture of the effect of a regressor in a non-linear multi-equation model with correlated disturbances. This result can obtain because coefficients do not reflect the regressor's influence that is due to its presence in the equations for the other choices and that could be transmitted to the equation of interest through the cross-correlated disturbances. ${ }^{13}$ Therefore, we focus instead on the marginal effects of the regressors, defined as the change in the probabilities of interest when there are appropriately 
defined $^{14}$ changes in the value of the regressors (coefficient estimates can be found in Table RA.1 in the Technical Appendix). We estimate probabilities, marginal effects and their standard errors via Monte Carlo simulation (Appendix A). Given that correlations of disturbances can have substantial effects on calculation of probabilities, we check their joint statistical significance (Appendix B).

\subsection{Model Performance}

An attractive feature of the model is that it allows the computation of a wide range of probabilities pertaining to participation, location, and spillovers. In Table 6, we display predicted participation rates, both conditional and unconditional, generated by estimated probabilities. Our estimates match closely the corresponding participation rates observed in the data, although the model was not calibrated with this objective in mind. This suggests that our model has considerable predictive power for population stockholding choices.

Our model makes it possible to estimate also marginal effects regarding ownership of any type of stocks, ${ }^{15}$ i.e. the question that existing participation literature normally addresses without differentiating across paths to stockholding. We thus compare marginal effects derived from our disaggregated model to the corresponding ones from a 'typical' participation regression that combines all stockholding modes together.

It is reassuring, both for the existing literature on stockholding participation and for our model, that estimated marginal effects for overall stockholding obtained from both models are very similar in sign, size, and patterns of significance (for brevity, these effects are reported in Table RA.2, cols. 1-4, in the Technical Appendix). This similarity suggests that the standard practice of merging three different stockholding modes is not misleading when overall stockholding participation is of interest. Our model, however, allows a novel anatomical probe into influences of observables on the different paths to stockholding, the correlations between unobservable influences, the hitherto unexplored link between asset participation and 
asset location, and the issue of participation spillovers across assets, in the context of a single estimation model consistent both with the data and with existing findings on overall participation.

\subsection{Correlations between Unobserved Factors}

As already discussed, our econometric model not only distinguishes between different stockholding modes but also allows choices of different saving instruments and stockholding vehicles to be correlated through the influence of unobserved factors. When we test for the joint significance of all cross-equation correlations, we indeed find that we can decisively reject the null of no significance (details can be found in Appendix B). When we test for statistical significance of each possible correlation individually, we find several (albeit not all) estimates of such correlations to be individually statistically significant. ${ }^{16}$

\section{The Different Paths to Stockholding}

Although direct stockholding, stock mutual funds, and stock retirement accounts all expose households to stockholding risk, they vary in their diversification properties, liquidity, and informational requirements on the part of investors. Given these differences, it is quite plausible that specific household characteristics will have differential contributions to participation across stockholding modes. Knowing the characteristics that make households more likely to choose particular stockholding modes constitutes important economic information, both for policy makers interested in distributional consequences of measures affecting asset returns and for practitioners seeking to gain insight on the portfolio choices of their potential clienteles.

In this Section, we employ our model to estimate contributions of various household characteristics to the use of each possible stockholding mode, controlling for other observed factors and allowing for correlations across model nodes induced by unobserved factors. For 
stockholding through mutual funds and retirement accounts, this consists of two steps: the marginal contribution to opening the account, and that to including stocks in it given ownership of the account. Results are presented in Table 7.

\subsection{Direct Stockholding}

In the first column of Table 7, we present marginal effects for direct stockownership. We typically think of direct stockholding as imposing heavy demands on the investor, by requiring considerable financial sophistication and ability to process complex new information quickly. Our findings underscore the importance of such considerations. The single most important contribution to direct stockholding comes from having a college degree, which raises participation probability by more than $15 \mathrm{pp}$ over that of a high school dropout. ${ }^{17}$ This result is likely linked to the superior knowledge and information processing ability provided by college education. Participation in direct stockholding is further increased by about $4 \mathrm{pp}$ if a household member works in the financial sector. This finding likely arises partly from financial knowledge and information that this member brings home and partly from bonuses and payments in stocks.

Although knowledge and information could also be imparted through informal social interactions, we do not find that asking friends or relatives for investment advice affects the probability of direct stockholding. At first glance this result seems to contradict the findings of Hong, Kubik and Stein (2004) on social interactions. However, it is consistent with their conjecture that social interactions may not foster or may even reduce participation in assets not widely held, as is the case with directly held stocks: a random prospective investor would have about one chance in five to find direct stockholders in her social circle. ${ }^{18}$

Is direct stockholding a more common investment choice among the risk-taking rich? Our findings support the view that household (taxable) resources play an important role: the semi-elasticity of real wealth is 2 pp while that of net financial wealth (directly held stocks 
excluded $)^{19}$ is .4 pp. Willingness to undertake substantial financial risk also makes a sizeable contribution (almost $9 \mathrm{pp}$ ). For given level of resources and willingness to take portfolio risk, background income risk associated with working in a high-risk sector lowers the chances of direct stockholding.

The estimated effect of the federal marginal tax rate is positive. ${ }^{20}$ Given that we are controlling for resources, a higher marginal tax rate means that the household is able to take fewer income tax deductions, but this does not discourage it from taxable direct stockholding. The more favorable tax treatment of dividends, the fact that capital gains are taxed only at realization, and the possibility of foregoing capital gains tax if stocks are passed on to descendants ('step up of basis') apparently combine to encourage direct stockholding among households facing higher marginal tax rates. The importance of such considerations is corroborated by estimated marginal effects of variables more directly linked to bequest motives: having received inheritance and planning to leave a bequest contribute about 5 and 6 pp respectively.

Finally, controlling for current financial resources, poor health has a sizeable negative contribution to direct stockholding of roughly $5 \mathrm{pp}$, which is consistent with existing findings (Rosen and $\mathrm{Wu}, 2004$ ) and with the view that direct stockholding imposes considerable demands on investing households.

\subsection{Stockholding through Mutual Funds}

Unlike direct stockholding, mutual funds are typically managed by professionals and are well-diversified. These features often lead to the presumption that mutual funds investments are open to all households because they do not require considerable financial sophistication and information gathering. Our findings are not consistent with this view, as can be seen in column 3 of Table 7. Educational attainment makes a considerable contribution to participation in mutual funds, with estimated marginal effects of a college degree at least as 
large as those for direct stockholding. The same is true for being in a managerial position. Having worked in the financial sector continues to play an important role, albeit somewhat smaller than for direct stockholding.

A possible source of these findings is that the proliferation of mutual funds has reintroduced informational requirements from the back door: households now face a need to collect information on how to choose among the huge variety of mutual funds and on how to monitor those who run them. ${ }^{21}$ Furthermore, a higher level of educational attainment makes it more likely to understand and appreciate the advantages of mutual fund investment, such as risk diversification. ${ }^{22}$ On the other hand, social interactions do not appear to reduce the relevance of financial knowledge. This result is consistent with the fact that mutual funds are not widely held; therefore, individuals that invest in them are not very likely to find in their social circle other mutual fund owners.

Column 5 in Table 7 reports marginal effects for the choice to hold stock mutual funds, given that the household owns any mutual funds at all. We find that opening a mutual fund account represents the major participation threshold. Once households take this first step, their further investment in stock mutual funds is not influenced in a statistically significant way by education, financial sophistication, resources, race, or financial attitudes (except for the willingness to assume financial risk). This finding suggests that the willingness to take risk is the key factor that influences the choice of mutual fund owners regarding whether to invest in stocks through these saving vehicles or not. More generally, it appears that, in the process of learning about mutual funds in general, investors acquire the relevant information about including stocks in their mutual fund holdings. As a result, such investment follows naturally, provided the investor is sufficiently willing to undertake financial risk. This is a new result that is due to the design of our model, and that, as discussed below, differentiates mutual funds from retirement accounts. Importantly, this differentiation would be impossible to uncover by just looking at descriptive statistics. ${ }^{23}$ 


\subsection{Stockholding in Retirement Accounts}

The use of retirement accounts as supplements to public pensions appears to be a policy priority because of the aging of the population and the associated increased ratio of retirees to working contributors to the public pension system. While descriptive statistics suggest that only about one in two US households own retirement accounts, we further show in this Section that such ownership is much more limited among households with low education or resources.

Marginal effects for ownership of retirement accounts are shown in column 7 of Table 7. It is striking that education has a sizeable role to play in retirement account ownership, even after controlling for other household characteristics and attitudes. The estimated size of the marginal effect of a college degree is $21 \mathrm{pp}$ compared to a household where the financial decision maker is a high-school dropout, but even that of a high-school certificate is about 14 pp. It is also notable that being white increases the probability of participation in retirement accounts by $9 \mathrm{pp}$ and that declaring poor health reduces it by $12 \mathrm{pp}$.

Richer households and those in a higher federal marginal tax bracket are substantially more likely to participate in retirement accounts. The latter result can be partly attributed to gains such households could reap from tax deferrals. Further, households with a managerial or professional occupation are by $6 \mathrm{pp}$ more likely to own retirement accounts, partly because such plans are sometimes offered to these occupational groups as a part of their compensation package. Being credit constrained reduces significantly the probability of investing in a retirement account. Given that we control for economic resources, this result is not simply due to being 'poorer'. Perceived inability to borrow probably discourages participation in plans that imply payment commitments over a prolonged period of time, for fear of being unable to meet them every period.

These findings suggest that there are significant obstacles to opening retirement accounts, even though ailing social insurance systems affect the population very broadly. The 
financial industry itself could help people overcome such obstacles, e.g. through more informative and targeted advertising. In addition, governments could design more effective informational campaigns and promote specially designed 'default options' in occupational retirement plans.

Our findings suggest some factors that are likely to facilitate or impede the process of spreading retirement account ownership. Based on our findings, the public perception regarding retirement accounts is still that of a quite risky financial instrument. Declared willingness to undertake significant risks for substantial returns contributes $8 \mathrm{pp}$ to the probability of participation, an estimate greater than that for mutual funds and comparable to the risky option of direct stockholding. On the other hand, social interactions are found to have a positive and significant effect on retirement account ownership (albeit at the 10\% level), consistent with the fact that they are held by a sizeable fraction of the population.

Interestingly, once households decide to participate in a retirement account, the choice to include stocks in such an account is sensitive to household characteristics that are similar to those contributing to direct stockholding (Table 7, col. 9). Our estimates suggest that willingness to bear the risk associated with stocks in retirement accounts is quite crucial when the objective is to provide for old age and the instrument is quite illiquid, as in the case of these accounts. Furthermore, stockholding through retirement accounts is fostered by being in a couple, having higher education, being white, having a long investment horizon, being a manager, a larger net real wealth, and an intention to leave a bequest. It is also encouraged by social interactions, thus strengthening their role found in the participation equation.

The contrast with mutual funds, where investment in stock mutual funds depends only on the willingness to take risk once mutual fund participation is decided, is quite striking. The fact that several factors contribute to the inclusion of stocks in retirement accounts helps us understand why not all retirement account owners make that choice, even if the majority do. 


\section{Asset Location: What Influences where Stockholders Keep their Stocks?}

People who decide to hold stocks face choices regarding the particular saving vehicles they use for stockholding: direct, in mutual funds, in retirement accounts. They differ in both risk and liquidity characteristics, as well as in tax treatment. The first two vehicles are taxable, whereas investments in the third one are most often tax deferred, i.e. investors pay taxes on them only when they collect their retirement income. The choices investors make have implications for practitioners dealing with these financial products, but importantly also for governments concerned about retirement preparedness and about the timing of tax revenues.

In terms of descriptive statistics, Table 3 shows the fractions of stockholders choosing each possible combination of stockholding modes, and allows us to see the most popular placement options. By adding the relevant percentages in the last column, it can be seen that almost three quarters of stockholders hold combinations that include stocks in retirement accounts, about $40 \%$ hold combinations that entail direct stockholding, while about $30 \%$ place stocks in mutual funds. This leads to the question of which characteristics favor each of the three not mutually exclusive choices, conditional on the household holding any stocks (i.e. conditional on being in at least one of the three nodes involving stocks). ${ }^{24}$

Table 8 reports a number of estimated conditional marginal effects. Single males tend to locate their investments in stocks held directly, while their female counterparts in stock mutual funds. Overconfidence of males found in other contexts such as stock trading (Barber and Odean, 2001), could be relevant for this observed pattern. Race continues to matter even among stockholders: minority households exhibit on average lower probabilities of holding stocks directly or through mutual funds (by about $6 \mathrm{pp}$ ), and by about half of this for putting stocks in retirement accounts.

The pattern of marginal effects for direct stockholding is quite similar whether they refer to participation or to asset location (as shown in Table 7, column 1 and Table 8, column 1), with the exception of being in poor health. This implies that whether we draw from the 
general population or we condition on the household being a stockholder does not make a significant difference with respect to the hurdle the household needs to pass in order to hold stocks directly. Intuitively, given that most stockholders own stocks in retirement accounts, conditioning on stock ownership essentially picks out stock retirement account owners. Our results, therefore, suggest that participation in stock retirement accounts does not particularly simplify the task of holding stocks directly.

As already discussed, passing the threshold for mutual fund ownership essentially paves the way to participation in stock mutual funds: household characteristics make a limited contribution to owning stock mutual funds, when the conditioning event is ownership of mutual funds. By contrast, the strong marginal effects for stock mutual fund ownership shown in col. 3 of Table 8 are due to the much weaker conditioning event of owning stocks in any form. Only about $36 \%$ of stockholders in our sample have also passed the participation threshold for mutual funds, leaving considerable room for characteristics to induce stock mutual fund ownership.

Moreover, it is striking that we find a number of significant marginal effects for placing stocks in retirement accounts when conditioning on any stockholding, even though $80 \%$ of stockholders own stock retirement accounts. As a result, these effects regard the remaining $20 \%$, who consider extending stockholding from taxable liquid instruments to the tax-deferred and less liquid retirement accounts. We find that such an extension is significantly encouraged by characteristics like working in a low-risk industry sector and being a manager, investment attitudes (expressing willingness to take above average financial risk, having a long investment horizon), race, and being subject to a higher marginal tax rate.

An alternative approach to modeling the location decision is to assume that the household first decides to hold stocks in any form, and then, conditional on deciding to own stocks, chooses one or more of the three possible modes in which to hold them (i.e., directly, in mutual funds, and in retirement accounts). Although this decision process seems harder to 
justify in view of trends observed in the data, ${ }^{25}$ estimating this alternative model can provide a useful test of robustness of our findings on stock location.

This alternative model (described in more detail in Technical Appendix RA.II), can be used to estimate four probabilities that are comparable to our baseline model: the unconditional probability to own stocks in any form, and the three conditional probabilities of holding stocks in a specific investment vehicle, conditional on owning stocks in any form. Reassuringly, the results for the first probability (shown in columns 5 and 6 of Table RA. 2 in the Technical Appendix) are very close to the ones we obtain from our multivariate model as well as those of the simple probit. The similarity of the results largely extends to marginal effects of the three conditional location probabilities that are shown in Table 9. Only in the case of stocks in retirement accounts do we note a few differences: in the alternative model, being white, in poor health, and talking to friends/relatives/work contacts about investments play no role, while using the Internet to obtain financial information does.

\section{Asset Participation Spillovers}

The high rate of ownership of retirement accounts is associated with rates of overall stock market participation of US households that hover around 50\%. Has the recent spread of retirement accounts encouraged stockholding in forms other than stock retirement accounts, leading to increased exposure to stockholding risk in taxable, liquid instruments such as mutual funds or directly held stocks? In this Section, we explore the implications of having passed the ownership threshold of retirement accounts for each stockholding mode: direct, through mutual funds, and through retirement accounts.

Table 6 reports observed participation rates and corresponding predictions of our model. Proportions of stockholders in any form are higher among retirement account owners than in the general population. Among such owners, $75 \%$ own stocks in their retirement accounts, $30 \%$ own stocks directly, and $23 \%$ own stocks in mutual funds. The corresponding 
proportions in the general population are much lower: 38\%, 19\%, and 14\%. As discussed above, our model matches quite well all conditional and unconditional participation rates observed in the data.

Based on these numbers, owning a retirement account implies higher probabilities of owning stocks in any form. Is this because the process of opening and maintaining a retirement account facilitates stock ownership, e.g. by familiarizing households with asset holding, investment opportunities, managed funds, etc? Or is it because households who have retirement accounts have characteristics and attitudes more conducive to stockholding anyway?

Table 4, which describes the various samples, shows that owners of retirement accounts are more likely to possess characteristics that facilitate stockholding. Relative to the general population, owners of retirement accounts are more likely to have a college degree, to be willing to assume above average financial risk, to have received inheritance and consider leaving a bequest, to have an investment horizon longer than 10 years, to be richer in income and wealth; and less likely to be liquidity constrained. Is there anything beyond this?

In exploring this issue, one needs to recognize that ownership of retirement accounts is not the result of a random assignment but of a choice that depends on household characteristics and attitudes explicitly modeled in our setup. If the process of acquiring and owning a retirement account itself significantly facilitates stockholding either directly or through stock mutual funds, we would expect household characteristics and attitudes to make less of a difference to stockholding through these modes once we condition on having retirement accounts. ${ }^{26}$ For example, having a college degree should make less of a difference to whether retirement account owners (rather than the general population) participate in directly held stocks or stock mutual funds. Technically, marginal effects on participation in these other forms of stockholding, conditional on retirement account ownership, should be 
insignificant or much smaller than the unconditional ones which refer to an investor picked randomly from the whole population.

Marginal effects conditional on ownership of retirement accounts are presented in Table 10 (col. 1 for directly held stocks; col. 3 for stock mutual funds). For comparison, column 1 in Table 7, and column 5 in Table 10 report the corresponding unconditional marginal effects. We observe that conditioning on participation in retirement accounts does not change the sign or significance of contributions of household characteristics, investment attitudes, and practices to participation in direct stockholding and in stock mutual funds; and, if anything, it

increases the estimated size of such contributions, including those linked to financial awareness and sophistication. Having a college degree or more and working or having worked in the financial sector are estimated to contribute more to participation in directly held stocks or in stock mutual funds when conditioning on participation in retirement accounts. The above findings challenge the hypothesis that the participation process for retirement accounts provides sufficient information and awareness to facilitate other forms of stockholding.

All in all, our findings imply that retirement account owners represent a pool more likely to invest in other forms of stockholding than the general population, but this is mainly because of characteristics that led them to buy retirement accounts in the first place rather than of any informational advantages gained through retirement account ownership itself.

\section{Concluding Remarks}

We have estimated an econometric model flexible enough to address in an integrated framework the interrelated issues of stock market participation, stock location, and participation spillovers. The model distinguishes between stockholding modes with different degrees of liquidity, riskiness, diversification, as well as differences in management requirements and transactions costs. Making such a distinction and allowing for correlated choices are supported by our econometric findings; predicted participation rates closely match 
the observed ones and correlations among unobservables are typically economically and statistically significant.

Our findings stress the importance of educational attainment and financial sophistication, even for ownership of assets held in managed accounts. Still, we find a striking difference between stock mutual funds and stocks in retirement accounts. The probability that any mutual fund owner holds stock mutual funds is basically the same regardless of characteristics. In contrast, stock retirement accounts tend to be chosen by retirement account owners with characteristics similar to those favoring direct stockholding in the general population. This is surprising, given the typically much greater degree of diversification in stock retirement accounts compared to individual stocks. The finding is consistent with a more limited willingness of households to take risks with retirement wealth than with investments in mutual funds.

Our findings on asset location and on participation spillovers suggest that even the choice to include stocks in one's retirement accounts per se does not imply that this household is more likely to branch out to direct stockholding or to holding stocks through mutual funds.

At first reading, there is an apparent contradiction between some of our results in these two Sections. In our analysis of asset location, we find that the contribution of characteristics like education and willingness to assume higher risks to owning stocks directly or through mutual funds remains essentially the same, whether this choice is made by a stockholder or by a randomly picked person in the general population. Given that $80 \%$ of stockholders own stock retirement accounts, this finding raises doubts as to whether even those who choose to include stocks in their retirement accounts will generally branch out to other forms of stockholding.

On the other hand, our Section on spillovers shows that retirement account owners represent a pool more likely to invest in other forms of stockholding than the general population. Although this may appear contradictory at first, our analysis of participation 
spillovers shows that this greater propensity of retirement account owners to invest in the other two stock vehicles is mainly due to the characteristics that led them to own retirement accounts in the first place rather than to any informational or other advantages gained through such ownership per se.

Our results have implications both for policy and for financial practice. First, they contribute to the discussion on financial literacy programs (see, e.g., Lusardi, forthcoming) by providing evidence that education and financial sophistication play a significant role in a much wider range of stock-related decisions than previously thought. These factors are linked not only to overall stockholding but also to investment in each of the three stockholding modes. ${ }^{27}$ They are also significant for stock location decisions; and for participation spillovers from retirement accounts to direct stockholding and to ownership of stock mutual funds.

Second, while owning retirement accounts makes stock ownership in all three modes more likely, the spread of retirement accounts does not promote investment in stocks uniformly across households, either within retirement accounts or outside them. For example, the less educated, less wealthy, more risk averse and those with shorter planning horizons are less likely to overcome the additional hurdle for stock ownership in any of the three modes, even if they own a retirement account. Therefore, appropriate use of default options in occupational retirement plans may well be needed to steer households towards or away from stockholding, depending on policy objectives.

Last but not least, our findings on the relevance of household characteristics could be of use to financial practitioners interested in targeting customers to market a broad range of financial products. Specifically, they could be used to pinpoint characteristics that make people more likely to invest in a particular financial product, such as mutual funds or retirement accounts, and in a particular stock vehicle; and to exploit the interdependencies and spillovers of household choices across a range of financial products on offer. 


\section{References}

Alessie R., S. Hochguertel, A. van Soest. 2004. "Ownership of Stocks and Mutual Funds: a Panel Data Analysis”. The Review of Economics and Statistics, 86, pp. 783-796.

Ameriks, J. and S. Zeldes, 2004. "How Do Household Portfolio Shares Vary with Age?". TIAA-CREF Working Paper.

Barber, B. and T. Odean, 2001. "Boys will be Boys: Gender, Overconfidence, and Common Stock Investment”. Quarterly Journal of Economics, 116(1), pp. 261-292.

Bertaut, C. and M. Starr-McCluer, 2001. "Household Portfolios in the United States". In Household Portfolios, L. Guiso, M. Haliassos, T. Jappelli (eds.). Cambridge: MIT Press.

Bilias Y., D. Georgarakos, and M. Haliassos, 2010. "Portfolio Inertia and Stock Market Fluctuations". Journal of Money, Credit and Banking, 42(4), pp. 715-742.

Bergstresser, D. and J. Poterba, 2004. "Asset Allocation and Asset Location: Household Evidence from the Survey of Consumer Finances". Journal of Public Economics, 88(910), pp. 1893-1915.

Bodie, Zvi, 1995. "On the Risk of Stocks in the Long Run". Financial Analysts Journal, May/June 1995. Available at SSRN: http://ssrn.com/abstract=271430

Bogan, V., 2008. "Stock Market Participation and the Internet". Journal of Financial and Quantitative Analysis, 43(1), pp. 191-212.

Campbell, J., 2006. “Household Finance”. Journal of Finance, 61, pp. 1553-1604.

Campbell, J. and L. Viceira, 2002. Strategic Asset Allocation: Portfolio Choice for Long-term Investors, Oxford: Oxford University Press.

Cappellari, L. and S.P. Jenkins, 2006. "Calculation of Multivariate Normal Probabilities by Simulation, with Applications to Maximum Simulated Likelihood Estimation". The Stata Journal, 6(2), pp. 156-189.

Cardak, B. and R. Wilkins, 2009. "The determinants of household risky asset holdings: Australian evidence on background risk and other factors". Journal of Banking and Finance, 33(5), pp. 850-860.

Carroll, C.D. and Andrew A. Samwick, 1997. "The Nature of Precautionary Wealth". Journal of Monetary Economics, 40(1), pp. 41-71.

Christelis, D., T. Jappelli, and M. Padula, 2010. "Cognitive Abilities and Portfolio Choice". European Economic Review, 54(1), pp. 18-38.

Christelis, D. and D. Georgarakos, 2008. "Investing at Home and Abroad: Different Costs, Different People?". Available at SSRN: http://ssrn.com/abstract=1086040

Cocco, J., F. Gomes and P. Maenhout, 2005. "Consumption and portfolio choice over the lifecycle". Review of Financial Studies, 18, pp. 491-533. 
Garlappi, L. and J. Huang, 2006. "Are Stocks Desirable in Tax-Deferred Accounts?". Journal of Public Economics, 90, pp. 2257-2283.

Gollier, C., 2001. The Economics of Risk and Time. Cambridge: MIT Press.

Gomes, F. and A. Michaelides, 2005. "Optimal Life-Cycle Asset Allocation: Understanding the Empirical Evidence". Journal of Finance, LX, pp. 869-904.

Greene, W., 1998. "Sample selection in credit-scoring models". Japan and the World Economy, 10, pp. 299-316.

Guiso L., M. Haliassos, and T. Jappelli (eds.), 2001. Household Portfolios. Cambridge: MIT Press.

Guiso, L., M. Haliassos, and T. Jappelli, 2003. "Household Stockholding in Europe: Where Do We Stand, Where Do We Go?’. Economic Policy, pp. 117-164.

Guiso, L. and T. Jappelli, 2005. "Awareness and stock market participation”. Review of Finance, 9, 537-567.

Guiso, L., P. Sapienza, and L. Zingales, 2008. "Trusting the Stock Market". Journal of Finance, 63(6), pp. 2557-2600.

Haliassos, M. and C. Bertaut, 1995. "Why Do So Few Hold Stocks?" The Economic Journal, 105, pp. 1110-1129.

Haliassos, M. and A. Michaelides, 2003. "Portfolio Choice and Liquidity Constraints". International Economic Review, 44, pp. 143-178.

Heaton, J. and D. Lucas, 2000. "Portfolio Choice in the Presence of Background Risk". The Economic Journal, 110, pp. 1-26.

Hong, H., J. Kubik, and J. Stein, 2004. "Social Interaction and Stock Market Participation". Journal of Finance, 59, pp. 137-163.

Investment Company Institute and Securities Industry Association, 2005. "Equity Ownership in America", published report.

Jenkins, S.P., L. Capellari, P. Lynn, A. Jäckel, and E. Sala, 2006. "Patterns of Consent: Evidence from a General Household Survey". Journal of the Royal Statistical Society A, 169, Part 4, pp. 701-722.

Karlsson, A., M. Massa, and A. Simonov, 2007. "Stock Market Participation and Pension Reform", in O.S. Mitchell, B.J. Soldo and B. Madrian (Eds.), Transitioning to Retirement: How Will Boomers Fare? Oxford: Oxford University Press.

Kennickell, A.B., 2000. "Wealth Measurement in the Survey of Consumer Finances: Methodology and Directions for Future Research".

http://www.federalreserve.gov/pub/oss/oss2/method.html. 
Li, K. H., T. E. Raghunathan, and D. B. Rubin, 1991. "Large Sample Significance Levels from Multiply Imputed Data using Moment-Based Statistics and an F Reference Distribution". Journal of the American Statistical Association, 86, pp. 1065-1073.

Lusardi, A., 2008. "Household Saving Behavior: The Role of Financial Literacy, Information and Financial Education Programs". Implications of Behavioral Economics for Economic Policy. Forthcoming.

Malmendier, U. and S. Nagel, 2010. "Depression Babies: Do Macroeconomic Experiences Affect Risk-Taking?". Quarterly Journal of Economics. Forthcoming.

Moore, K., 2003. "The Effects of the 1986 and 1993 Tax Reforms on Self-Employment." Mimeo, Finance and Economics Discussion Series 2004-05, Board of Governors of the Federal Reserve System.

Rosen, H. and S. Wu, 2004. "Portfolio Choice and Health Status". Journal of Financial Economics, 72(3), pp. 457-484.

Shum, P. and M. Faig, 2006. "What explains household stock holdings?" Journal of Banking and Finance, 30(9), pp. 2579-2597.

Train, K., 2003. Discrete Choice Methods with Simulation. Cambridge: Cambridge University Press.

Van de Ven, W.P.M.M. and B.M.S.Van Praag, 1981. "The Demand for Deductibles in Private Health Insurance: a Probit Model with Sample Selection”. Journal of Econometrics, 17, pp. 229-252.

Van Rooij, M., R. Alessie, and A. Lusardi, 2007. "Financial Literacy and Stock Market Participation”. Working Paper, October 2007.

Viceira, L., 2001. "Optimal Portfolio Choice for Long-Horizon Investors with Nontradable Labor Income”. Journal of Finance, 56, pp. 433-470. 


\section{Appendix A: Estimates and Standard Errors of Probabilities and Marginal Effects}

Given that probabilities and marginal effects are non-linear functions of the estimated coefficients, we calculate them by simulation. We proceed as follows: i) we draw from the distribution of the maximum likelihood coefficients assuming that they are distributed normally with means and variance-covariance matrix equal to the maximum likelihood estimates; ii) for a given parameter draw we compute the probabilities and marginal effects for each household and then we take the weighted average of those magnitudes across households, i.e., we compute the average magnitude corresponding to that $\operatorname{draw}^{28}$; iii) the final estimate of the magnitude of interest and its standard error are then computed as the mean and standard deviation respectively of the distribution of the average magnitudes in (ii) across all parameter draws.

\section{Appendix B: Tests of Correlations Across Disturbances}

We use the F-test suggested by Li, Raghunathan and Rubin (1991) to account for the uncertainty induced by multiple imputation. We first perform the test by including all correlation coefficients except two, namely the correlations $\rho_{\mathrm{vn}}$ and $\rho_{\varepsilon e}$ of the errors that reflect selection within the two saving vehicles of mutual funds and retirement accounts. The value of the F-statistics is equal to 51.3 (p-value: 0), which strongly rejects the null hypothesis of zero correlation of the errors across the three saving vehicles (direct stocks, mutual funds and retirement accounts) and the two second stage equations. When we add the correlation of the errors within the two saving vehicles of mutual funds and retirement accounts the Fstatistic is equal to 42.5 (p-value: 0), again strongly rejecting the null. Thus, we cannot ignore the correlations of the unobserved factors across equations when computing the probabilities of asset choices of interest. 
Table 1: Ownership Rates

\begin{tabular}{|c|c|c|c|c|c|}
\hline Year & $\begin{array}{l}\text { Stocks } \\
\text { Directly }\end{array}$ & $\begin{array}{l}\text { Mutual } \\
\text { Funds }\end{array}$ & $\begin{array}{c}\text { Stocks in } \\
\text { Mutual Funds } \\
\text { [among } \\
\text { Mutual Fund } \\
\text { Owners] }\end{array}$ & $\begin{array}{c}\text { Retirement } \\
\text { Accounts }\end{array}$ & $\begin{array}{l}\text { Stocks in } \\
\text { Retirement } \\
\text { Accounts } \\
\text { [among } \\
\text { Retirement } \\
\text { Account } \\
\text { Owners] }\end{array}$ \\
\hline 1995 & 15.2 & 15.3 & $\begin{array}{c}11.3 \\
{[74.1]}\end{array}$ & 46.5 & $\begin{array}{c}30.3 \\
{[65.2]}\end{array}$ \\
\hline 1998 & 19.2 & 19.5 & $\begin{array}{c}15.2 \\
{[78.0]}\end{array}$ & 50.8 & $\begin{array}{c}39.2 \\
{[77.0]}\end{array}$ \\
\hline 2001 & 21.3 & 21.1 & $\begin{array}{c}16.7 \\
{[79.0]}\end{array}$ & 54 & $\begin{array}{c}43.4 \\
{[80.5]}\end{array}$ \\
\hline 2004 & 20.7 & 17.9 & $\begin{array}{c}14.3 \\
{[79.9]}\end{array}$ & 52.1 & $\begin{array}{c}39.6 \\
{[76.0]}\end{array}$ \\
\hline
\end{tabular}

Notes: Data from the 1995, 1998, 2001 and 2004 waves of the SCF. The reported statistics are weighted and corrected for multiple imputation. 
Table 2: Stock Ownership Rates among Stocks Owners

\begin{tabular}{cccc}
\hline Year & $\begin{array}{c}\text { Stocks } \\
\text { Directly }\end{array}$ & $\begin{array}{c}\text { Stocks in } \\
\text { Mutual } \\
\text { Funds }\end{array}$ & $\begin{array}{c}\text { Stocks in } \\
\text { Retirement } \\
\text { Accounts }\end{array}$ \\
\hline $\mathbf{1 9 9 5}$ & 37.7 & 28.0 & 75.0 \\
$\mathbf{1 9 9 8}$ & 39.3 & 31.1 & 80.1 \\
$\mathbf{2 0 0 1}$ & 41.0 & 32.1 & 83.6 \\
$\mathbf{2 0 0 4}$ & 42.5 & 29.4 & 81.5 \\
\hline
\end{tabular}

Notes: Data from the 1995, 1998, 2001 and 2004 waves of the SCF. The reported statistics are weighted and corrected for multiple imputation. 
Table 3: Combinations of Stock Investments Held by Stock Owners

\begin{tabular}{cccc}
\hline $\begin{array}{c}\text { Directly Held } \\
\text { Stocks }\end{array}$ & $\begin{array}{c}\text { Stocks in } \\
\text { Mutual Funds }\end{array}$ & $\begin{array}{c}\text { Stocks in } \\
\text { Retirement } \\
\text { Accounts }\end{array}$ & $\begin{array}{c}\text { Proportion } \\
\text { owning the } \\
\text { Combination }\end{array}$ \\
\hline Yes & No & No & 10 \\
No & Yes & No & 6.4 \\
No & No & Yes & 43.3 \\
Yes & Yes & No & 3.2 \\
No & Yes & Yes & 9.9 \\
Yes & No & Yes & 16.5 \\
Yes & Yes & Yes & 10.7 \\
& & & \\
\hline
\end{tabular}

Notes: Pooled data from the 1995, 1998, 2001 and 2004 waves of the SCF. The reported statistics are weighted and corrected for multiple imputation. 
Table 4: Household Characteristics by Asset Choice

\begin{tabular}{|c|c|c|c|c|c|c|}
\hline Variable & Whole sample & $\begin{array}{l}\text { Owns stocks } \\
\text { directly }\end{array}$ & $\begin{array}{l}\text { Owns mutual } \\
\text { funds }\end{array}$ & $\begin{array}{l}\text { Has stocks in } \\
\text { mutual funds }\end{array}$ & $\begin{array}{c}\text { Owns } \\
\text { retirement } \\
\text { accounts }\end{array}$ & $\begin{array}{c}\text { Has stocks in } \\
\text { retirement } \\
\text { accounts }\end{array}$ \\
\hline Age (mean) & 48.9 & 51.3 & 51.9 & 51.2 & 48.2 & 46.7 \\
\hline Couple & 0.588 & 0.722 & 0.703 & 0.716 & 0.698 & 0.715 \\
\hline Single male & 0.140 & 0.124 & 0.110 & 0.110 & 0.114 & 0.117 \\
\hline Has children & 0.435 & 0.409 & 0.393 & 0.404 & 0.467 & 0.483 \\
\hline High school graduate & 0.509 & 0.380 & 0.359 & 0.362 & 0.469 & 0.447 \\
\hline College degree or more & 0.337 & 0.583 & 0.612 & 0.611 & 0.472 & 0.507 \\
\hline Self-employed & 0.113 & 0.160 & 0.169 & 0.164 & 0.124 & 0.124 \\
\hline Retired & 0.240 & 0.227 & 0.234 & 0.224 & 0.157 & 0.116 \\
\hline Unemployed/Inactive & 0.051 & 0.025 & 0.025 & 0.024 & 0.022 & 0.018 \\
\hline White & 0.762 & 0.897 & 0.910 & 0.908 & 0.841 & 0.851 \\
\hline Poor health & 0.061 & 0.024 & 0.018 & 0.016 & 0.022 & 0.016 \\
\hline $\begin{array}{l}\text { Willingness to take above average } \\
\text { financial risk }\end{array}$ & 0.205 & 0.365 & 0.359 & 0.375 & 0.288 & 0.334 \\
\hline Investment horizon > 10 yrs & 0.143 & 0.214 & 0.245 & 0.252 & 0.196 & 0.217 \\
\hline Plans to leave a bequest & 0.293 & 0.431 & 0.444 & 0.445 & 0.356 & 0.369 \\
\hline Has received inheritance & 0.199 & 0.320 & 0.339 & 0.345 & 0.246 & 0.245 \\
\hline Credit constrained & 0.224 & 0.124 & 0.085 & 0.089 & 0.167 & 0.166 \\
\hline Works/ed in the Financial Sector & 0.204 & 0.289 & 0.280 & 0.280 & 0.251 & 0.267 \\
\hline Has a managerial position & 0.330 & 0.514 & 0.533 & 0.541 & 0.473 & 0.518 \\
\hline Federal marginal tax rate (mean) & 0.173 & 0.232 & 0.230 & 0.232 & 0.220 & 0.229 \\
\hline $\begin{array}{l}\text { Asks Friends/Relatives/Work } \\
\text { contacts for financial information }\end{array}$ & 0.360 & 0.366 & 0.346 & 0.350 & 0.374 & 0.391 \\
\hline $\begin{array}{l}\text { Uses Internet to obtain financial } \\
\text { information }\end{array}$ & 0.111 & 0.205 & 0.183 & 0.189 & 0.155 & 0.179 \\
\hline Works in high-risk industry sector & 0.091 & 0.053 & 0.061 & 0.065 & 0.083 & 0.076 \\
\hline Non-investment income (median) & 37,788 & 66,566 & 65,449 & 67,281 & 58,985 & 63,871 \\
\hline Net real wealth (median) & 57,968 & 157,767 & 161,654 & 162,894 & 99,271 & 101,289 \\
\hline Net financial wealth (median) & 9,943 & 146,726 & 168,318 & 176,365 & 61,123 & 68,988 \\
\hline
\end{tabular}

Notes: Pooled data from the 1995, 1998, 2001 and 2004 waves of the SCF. The reported statistics are weighted and corrected for multiple imputation. 
For each respondent $i=1, \ldots, \mathrm{N}$ :

(1) Owns stocks directly

$D S_{i}^{*}=X_{i}^{\prime} \theta+u_{i} \quad D S_{i}=I\left(D S_{i}^{*}>0\right)$

(2) Owns mutual funds

$M_{i}^{*}=Z_{i}^{\prime} \alpha+v_{i} \quad M_{i}=I\left(M_{i}^{*}>0\right)$

(3) Holds stocks in mutual funds

$M S_{i}^{*}=W_{i}^{\prime} \beta+n_{i} \quad M S_{i}=I\left(M S_{i}^{*}>0\right)$ if $M_{i}=1$, else unobserved

(4) Owns retirement accounts

$R_{i}^{*}=G_{i}^{\prime} \gamma+\varepsilon_{i} \quad R_{i}=I\left(R_{i}^{*}>0\right)$

(5) Holds stocks in retirement accounts

$R S_{i}^{*}=Y_{i}^{\prime} \delta+e_{i}$

$R S_{i}=I\left(R S_{i}^{*}>0\right)$ if $R_{i}=1$, else unobserved

(6) Error terms

$\left(u_{i}, \nu_{i}, n_{i}, \varepsilon_{i}, e_{i}\right) \sim \Phi_{5}(0, \Omega)$, where $\Omega$ is a symmetric matrix with typical element $\rho_{h j}=\rho_{j h}$ for $h, j \in\{u, v, n, \varepsilon, e\}$ and $j \neq h$, and $\rho_{j j}=1$ for all $j$. The errors in each equation are assumed to be orthogonal to the predictors.

Notes: $I($.$) is an indicator function equal to one if its argument is true, and zero otherwise.$ $\Phi_{5}($.$) denotes the five-variate normal distribution function.$ 
Table 6: Observed and Predicted Participation Rates

\begin{tabular}{|c|c|c|c|}
\hline \multirow{3}{*}{ Asset Choice } & \multirow{3}{*}{$\begin{array}{c}(1) \\
\begin{array}{c}\text { Proportions } \\
\text { in Data }\end{array}\end{array}$} & \multirow{2}{*}{\multicolumn{2}{|c|}{$\begin{array}{c}(2) \\
\begin{array}{c}\text { Predicted Proportions by } \\
\text { the Model }\end{array}\end{array}$}} \\
\hline & & & \\
\hline & & Estimate & Std. Error \\
\hline Owns stocks directly & 0.19 & 0.21 & $0.004 * * *$ \\
\hline Owns mutual funds & 0.18 & 0.20 & $0.004 * * *$ \\
\hline Owns retirement accounts & 0.51 & 0.51 & $0.005 * * *$ \\
\hline Owns stocks in mutual funds & 0.14 & 0.15 & $0.005 * * *$ \\
\hline Owns stocks in retirement accounts & 0.38 & 0.39 & $0.006 * * *$ \\
\hline Owns stocks in mutual funds $\mid$ owns mutual funds & 0.78 & 0.79 & $0.022 * * *$ \\
\hline Owns stocks in retirement accounts $\mid$ owns retirement accounts & 0.75 & 0.76 & $0.008 * * *$ \\
\hline Owns stocks directly | owns mutual funds & 0.45 & 0.48 & $0.013 * * *$ \\
\hline Owns stocks directly $\mid$ owns retirement accounts & 0.30 & 0.33 & $0.008 * * *$ \\
\hline Owns stocks directly | owns stocks in mutual funds & 0.46 & 0.50 & $0.013 * * *$ \\
\hline Owns stocks directly $\mid$ owns stocks in retirement accounts & 0.34 & 0.36 & $0.009 * * *$ \\
\hline Owns mutual funds $\mid$ owns stocks directly & 0.44 & 0.44 & $0.012 * * *$ \\
\hline Owns mutual funds $\mid$ owns retirement accounts & 0.29 & 0.31 & $0.007 * * *$ \\
\hline Owns retirement accounts | owns stocks directly & 0.81 & 0.78 & $0.010 * * *$ \\
\hline Owns retirement accounts $\mid$ owns mutual funds & 0.81 & 0.80 & $0.010 * * *$ \\
\hline Owns stocks in mutual funds | owns stocks directly & 0.34 & 0.35 & $0.013 * * *$ \\
\hline Owns stocks in mutual funds $\mid$ owns retirement accounts & 0.23 & 0.25 & $0.009 * * *$ \\
\hline Owns stocks in mutual funds $\mid$ owns stocks in retirement accounts & 0.26 & 0.27 & $0.011 * * *$ \\
\hline Owns stocks in retirement accounts | owns stocks directly & 0.68 & 0.65 & $0.012 * * *$ \\
\hline Owns stocks in retirement accounts $\mid$ owns stocks in mutual funds & 0.68 & 0.68 & $0.014 * * *$ \\
\hline Owns stocks in any form & 0.48 & 0.50 & $0.005 * * *$ \\
\hline Owns stocks directly | owns stocks in any form & 0.40 & 0.43 & $0.008 * * *$ \\
\hline Owns stocks in mutual funds $\mid$ owns stocks in any form & 0.30 & 0.31 & $0.010 * * *$ \\
\hline Owns stocks in retirement accounts $\mid$ owns stocks in any form & 0.80 & 0.79 & $0.008 * * *$ \\
\hline
\end{tabular}

Notes: All unconditional probabilities are average probabilities calculated over the full sample. All conditional probabilities are average probabilities calculated over the sub-sample we condition on. SCF pooled data from 1995, 1998, 2001, 2004 using survey weights and correcting for multiple imputation. ***,*** denote significance at $1 \%$, $5 \%$ and $10 \%$ respectively. 
Table 7: Average Marginal Effects from Multivariate Probit Model with Selection

\begin{tabular}{|c|c|c|c|c|c|c|c|c|c|c|}
\hline \multirow{3}{*}{ Variable } & (1) & $(2)$ & (3) & (4) & $(5)$ & (6) & (7) & (8) & (9) & (10) \\
\hline & \multicolumn{2}{|c|}{ Directly Held Stocks } & \multicolumn{2}{|c|}{ Mutual Funds } & \multicolumn{2}{|c|}{$\begin{array}{l}\text { Stocks in Mutual } \\
\text { Funds } \\
\text { (Conditional) }\end{array}$} & \multicolumn{2}{|c|}{ Retirement Accounts } & \multicolumn{2}{|c|}{$\begin{array}{c}\text { Stocks in Retirement } \\
\text { Accounts } \\
\text { (Conditional) }\end{array}$} \\
\hline & M. Eff. & Std. Error & M. Eff. & Std. Error & M. Eff. & Std. Error & M. Eff. & Std. Error & M. Eff. & Std. Error \\
\hline Couple & 0.050 & $0.008 * * *$ & 0.014 & $0.008 *$ & 0.042 & $0.023 *$ & 0.072 & $0.009 * * *$ & 0.052 & $0.014 * * *$ \\
\hline Single male & 0.028 & $0.010 * * *$ & -0.023 & $0.010 * *$ & 0.024 & 0.028 & -0.025 & $0.013 * *$ & 0.024 & 0.020 \\
\hline High school graduate & 0.078 & $0.009 * * *$ & 0.084 & $0.008 * * *$ & 0.018 & 0.044 & 0.139 & $0.013 * * *$ & 0.061 & $0.024 * *$ \\
\hline College degree or more & 0.159 & $0.011 * * *$ & 0.182 & $0.010 * * *$ & -0.014 & 0.044 & 0.210 & $0.014 * * *$ & 0.092 & $0.026 * * *$ \\
\hline White & 0.066 & $0.008 * * *$ & 0.068 & $0.008 * * *$ & 0.000 & 0.026 & 0.086 & $0.010 * * *$ & 0.072 & $0.017 * * *$ \\
\hline Poor health & -0.050 & $0.015 * * *$ & -0.072 & $0.013 * * *$ & -0.048 & 0.051 & -0.124 & $0.019 * * *$ & -0.065 & $0.037 *$ \\
\hline Willingness to take above average financial risk & 0.087 & $0.007 * * *$ & 0.062 & $0.007 * * *$ & 0.022 & $0.013 *$ & 0.083 & $0.009 * * *$ & 0.089 & $0.011 * * *$ \\
\hline Investment horizon $>10 \mathrm{yrs}$ & 0.026 & $0.007 * * *$ & 0.044 & $0.007 * * *$ & 0.006 & 0.013 & 0.059 & $0.010 * * *$ & 0.036 & $0.012 * * *$ \\
\hline $\begin{array}{l}\text { Asks Friends/Relatives/Work contacts for } \\
\text { financial information }\end{array}$ & 0.002 & 0.006 & -0.002 & 0.006 & 0.008 & 0.013 & 0.013 & $0.007 *$ & 0.023 & $0.011 * *$ \\
\hline Uses Internet to obtain financial information & 0.067 & $0.009 * * *$ & 0.051 & $0.009 * * *$ & 0.009 & 0.017 & 0.064 & $0.012 * * *$ & 0.038 & $0.015 * *$ \\
\hline Non-investment income & 0.000 & 0.001 & -0.001 & 0.001 & 0.002 & 0.003 & 0.012 & $0.002 * * *$ & 0.000 & 0.002 \\
\hline Net real wealth & 0.020 & $0.002 * * *$ & 0.010 & $0.001 * * *$ & -0.003 & 0.003 & 0.014 & $0.001 * * *$ & 0.004 & $0.002 * *$ \\
\hline Net financial wealth & 0.004 & $0.000 * * *$ & 0.004 & $0.000 * * *$ & -0.002 & 0.002 & 0.002 & $0.000 * * *$ & 0.000 & 0.000 \\
\hline Intention to leave a bequest & 0.064 & $0.007 * * *$ & 0.054 & $0.006 * * *$ & -0.008 & 0.015 & 0.043 & $0.008 * * *$ & 0.029 & $0.010 * * *$ \\
\hline Has received inheritance & 0.046 & $0.006 * * *$ & 0.044 & $0.006 * * *$ & 0.016 & 0.014 & 0.038 & $0.009 * * *$ & 0.013 & 0.010 \\
\hline Credit constrained & -0.007 & 0.008 & -0.060 & $0.009 * * *$ & -0.014 & 0.034 & -0.048 & $0.009 * * *$ & -0.011 & 0.015 \\
\hline Works/ed in the Financial Sector & 0.040 & $0.007 * * *$ & 0.025 & $0.007 * * *$ & -0.020 & 0.014 & 0.015 & $0.008 *$ & 0.007 & 0.011 \\
\hline Works in high-risk industry sector & -0.045 & $0.009 * * *$ & -0.017 & $0.010 *$ & 0.009 & 0.025 & -0.037 & $0.012 * * *$ & -0.071 & $0.017 * * *$ \\
\hline Has a managerial position & 0.024 & $0.007 * * *$ & 0.034 & $0.007 * * *$ & 0.012 & 0.016 & 0.058 & $0.009 * * *$ & 0.032 & $0.011 * * *$ \\
\hline Federal marginal tax rate & 0.012 & $0.002 * * *$ & 0.011 & $0.002 * * *$ & 0.002 & 0.004 & 0.024 & $0.002 * * *$ & 0.010 & $0.003 * * *$ \\
\hline \multicolumn{11}{|c|}{ Correlation terms } \\
\hline Correlation with Directly Held Stocks & & & 0.232 & $0.015 * * *$ & 0.098 & 0.062 & 0.189 & $0.018 * * *$ & 0.188 & $0.030 * * *$ \\
\hline Correlation with Mutual Funds & & & & & 0.119 & 0.387 & 0.218 & $0.017 * * *$ & 0.189 & $0.034 * * *$ \\
\hline Correlation with Mutual Funds in Stocks & & & & & & & 0.074 & 0.064 & 0.075 & 0.056 \\
\hline Correlation with Retirement Accounts & & & & & & & & & 0.490 & 0.329 \\
\hline Log likelihood & \multicolumn{10}{|c|}{$-31,550.4$} \\
\hline Number of observations & & & & & 17, & & & & & \\
\hline
\end{tabular}

Notes: Pooled data from the 1995, 1998, 2001 and 2004 waves of the SCF. All estimates are corrected for multiple imputation. ***,*** denote significance at $1 \%, 5 \%$ and $10 \%$ respectively. Additional regressors include a second degree polynomial in age, a dummy for having children, dummies for employment status, and dummies for years 1998, 2001, 2004. 
Table 8: Average Marginal Effects on the Probability of Using a Stockholding Mode, Conditional on Stock Ownership

\begin{tabular}{|c|c|c|c|c|c|c|}
\hline \multirow{3}{*}{ Variable } & $(\mathbf{1})$ & (2) & (3) & (4) & (5) & (6) \\
\hline & \multicolumn{2}{|c|}{$\begin{array}{c}\text { Directly Held } \\
\text { Stocks, Conditional } \\
\text { on Having Stocks in } \\
\text { any Form }\end{array}$} & \multicolumn{2}{|c|}{$\begin{array}{c}\text { Stocks in Mutual } \\
\text { Funds, Conditional } \\
\text { on Having Stocks in } \\
\text { any Form }\end{array}$} & \multicolumn{2}{|c|}{$\begin{array}{l}\text { Stocks in Retiremen } \\
\text { Accounts, } \\
\text { Conditional on } \\
\text { Having Stocks in } \\
\text { any Form }\end{array}$} \\
\hline & M. Eff. & Std. Error & M. Eff. & Std. Error & M. Eff. & Std. Error \\
\hline Couple & 0.051 & $0.014 * * *$ & 0.001 & 0.014 & 0.037 & $0.010 * * *$ \\
\hline Single male & 0.057 & $0.019 * * *$ & -0.032 & $0.017 *$ & -0.015 & 0.015 \\
\hline High school graduate & 0.072 & $0.019 * * *$ & 0.090 & $0.018 * * *$ & 0.016 & 0.016 \\
\hline College degree or more & 0.159 & $0.021 * * *$ & 0.172 & $0.019 * * *$ & 0.011 & 0.016 \\
\hline White & 0.062 & $0.015 * * *$ & 0.058 & $0.015 * * *$ & 0.027 & $0.012 * *$ \\
\hline Poor health & -0.016 & 0.033 & -0.078 & $0.026 * * *$ & -0.054 & $0.025 * *$ \\
\hline $\begin{array}{l}\text { Willingness to take above average } \\
\text { financial risk }\end{array}$ & 0.084 & $0.010 * * *$ & 0.046 & $0.009 * * *$ & 0.039 & $0.007 * * *$ \\
\hline Investment horizon $>10 \mathrm{yrs}$ & 0.012 & 0.011 & 0.039 & $0.010 * * *$ & 0.028 & $0.008 * * *$ \\
\hline $\begin{array}{l}\text { Asks Friends/Relatives/Work } \\
\text { contacts for financial information }\end{array}$ & -0.006 & 0.010 & -0.006 & 0.009 & 0.019 & $0.007 * * *$ \\
\hline $\begin{array}{l}\text { Uses Internet to obtain financial } \\
\text { information }\end{array}$ & 0.072 & $0.014 * * *$ & 0.042 & $0.013 * * *$ & 0.013 & 0.011 \\
\hline Non-investment income & -0.002 & 0.002 & -0.003 & 0.002 & 0.006 & $0.002 * * *$ \\
\hline Net real wealth & 0.027 & $0.003 * * *$ & 0.005 & $0.002 * * *$ & -0.001 & 0.001 \\
\hline Net financial wealth & 0.004 & $0.001 * * *$ & 0.003 & $0.001 * * *$ & 0.000 & 0.000 \\
\hline Intention to leave a bequest & 0.078 & $0.011 * * *$ & 0.045 & $0.010 * * *$ & -0.005 & 0.007 \\
\hline Has received inheritance & 0.053 & $0.010 * * *$ & 0.049 & $0.009 * * *$ & -0.006 & 0.008 \\
\hline Credit constrained & 0.018 & 0.015 & -0.082 & $0.017 * * *$ & -0.011 & 0.011 \\
\hline Works/ed in the Financial Sector & 0.056 & $0.011 * * *$ & 0.016 & 0.010 & -0.013 & 0.008 \\
\hline Works in high-risk industry sector & -0.052 & $0.017 * * *$ & 0.009 & 0.019 & -0.030 & $0.013 * *$ \\
\hline Has a managerial position & 0.010 & 0.011 & 0.030 & $0.011 * * *$ & 0.028 & $0.008 * * *$ \\
\hline Federal marginal tax rate & 0.010 & $0.003 * * *$ & 0.007 & $0.003 * * *$ & 0.010 & $0.002 * * *$ \\
\hline
\end{tabular}


Table 9: Average Marginal Effects on the Probability of Using a Stockholding Mode, Conditional on Stock Ownership, Alternative Model

\begin{tabular}{|c|c|c|c|c|c|c|}
\hline \multirow{3}{*}{ Variable } & (1) & (2) & (3) & (4) & $(5)$ & (6) \\
\hline & \multicolumn{2}{|c|}{$\begin{array}{c}\text { Directly Held } \\
\text { Stocks, Conditional } \\
\text { on Having Stocks in } \\
\text { any Form }\end{array}$} & \multicolumn{2}{|c|}{$\begin{array}{c}\text { Stocks in Mutual } \\
\text { Funds, Conditional } \\
\text { on Having Stocks in } \\
\text { any Form }\end{array}$} & \multicolumn{2}{|c|}{$\begin{array}{c}\text { Stocks in Retirement } \\
\text { Accounts, } \\
\text { Conditional on } \\
\text { Having Stocks in } \\
\text { any Form } \\
\end{array}$} \\
\hline & M. Eff. & Std. Error & M. Eff. & Std. Error & M. Eff. & Std. Error \\
\hline Couple & 0.048 & $0.015 * * *$ & 0.007 & 0.010 & 0.066 & $0.017 * * *$ \\
\hline Single male & 0.064 & $0.020 * * *$ & -0.025 & $0.013 *$ & -0.019 & 0.021 \\
\hline High school graduate & 0.033 & 0.027 & 0.035 & $0.016 * *$ & -0.004 & 0.030 \\
\hline College degree or more & 0.113 & $0.027 * * *$ & 0.109 & $0.021 * * *$ & 0.009 & 0.030 \\
\hline White & 0.058 & $0.015 * * *$ & 0.053 & $0.012 * * *$ & 0.026 & 0.019 \\
\hline Poor health & 0.014 & 0.038 & -0.041 & $0.021 * *$ & -0.059 & 0.037 \\
\hline $\begin{array}{l}\text { Willingness to take above average } \\
\text { financial risk }\end{array}$ & 0.083 & $0.012 * * *$ & 0.073 & $0.011 * * *$ & 0.088 & $0.015 * * *$ \\
\hline Investment horizon $>10$ yrs & 0.019 & $0.011 *$ & 0.048 & $0.010 * * *$ & 0.067 & $0.014 * * *$ \\
\hline $\begin{array}{l}\text { Asks Friends/Relatives/Work contacts } \\
\text { for financial information }\end{array}$ & -0.013 & 0.010 & -0.004 & 0.007 & -0.001 & 0.012 \\
\hline $\begin{array}{l}\text { Uses Internet to obtain financial } \\
\text { information }\end{array}$ & 0.080 & $0.014 * * *$ & 0.051 & $0.012 * * *$ & 0.051 & $0.018 * * *$ \\
\hline Non-investment income & -0.002 & 0.002 & 0.001 & 0.002 & 0.010 & $0.003 * * *$ \\
\hline Net real wealth & 0.025 & $0.003 * * *$ & 0.005 & $0.002 * * *$ & -0.004 & 0.002 \\
\hline Net financial wealth & 0.004 & $0.001 * * *$ & 0.003 & $0.001 * * *$ & 0.000 & 0.000 \\
\hline Intention to leave a bequest & 0.077 & $0.011 * * *$ & 0.047 & $0.009 * * *$ & 0.019 & 0.012 \\
\hline Has received inheritance & 0.051 & $0.011 * * *$ & 0.047 & $0.010 * * *$ & 0.006 & 0.012 \\
\hline Credit constrained & 0.000 & 0.016 & -0.056 & $0.012 * * *$ & -0.028 & 0.018 \\
\hline Works/ed in the Financial Sector & 0.051 & $0.011 * * *$ & 0.020 & $0.008 * * *$ & -0.007 & 0.012 \\
\hline Works in high-risk industry sector & -0.058 & $0.017 * * *$ & -0.010 & 0.012 & -0.058 & $0.020 * * *$ \\
\hline Has a managerial position & 0.018 & 0.012 & 0.036 & $0.009 * * *$ & 0.026 & $0.014 *$ \\
\hline Federal marginal tax rate & 0.000 & $0.000 * * *$ & 0.000 & $0.000 * * *$ & 0.000 & $0.000 * * *$ \\
\hline
\end{tabular}

Notes: Pooled data from the 1995, 1998, 2001 and 2004 waves of the SCF. The results for income, net real and non equity financial wealth represent median semi-elasticities, while for the remaining variables average marginal effects. All estimates are corrected for multiple imputation. $* * * * * * *$ denote significance at $1 \%, 5 \%$ and $10 \%$ respectively. Additional regressors include a second degree polynomial in age, a dummy for having children, dummies for employment status, and dummies for years 1998, $2001,2004$. 
Table 10: Average Marginal Effects on the Probability of Holding Stocks Directly or in Mutual Funds

\begin{tabular}{|c|c|c|c|c|c|c|}
\hline \multirow{3}{*}{ Variable } & \multirow{2}{*}{\multicolumn{2}{|c|}{$\begin{array}{c}(1) \\
\text { Directly Held } \\
\text { Stocks, Conditional } \\
\text { on Holding any } \\
\text { Retirement Accounts }\end{array}$}} & (3) & (4) & (5) & (6) \\
\hline & & & \multicolumn{2}{|c|}{$\begin{array}{c}\text { Stocks in Mutual } \\
\text { Funds, Conditional } \\
\text { on Holding any } \\
\text { Retirement Accounts }\end{array}$} & \multicolumn{2}{|c|}{$\begin{array}{c}\text { Stocks in Mutual } \\
\text { Funds, } \\
\text { Unconditional }\end{array}$} \\
\hline & M. Eff. & Std. Error & M. Eff. & Std. Error & M. Eff. & Std. Error \\
\hline Couple & 0.063 & $0.011 * * *$ & 0.022 & $0.011 * *$ & 0.019 & $0.007 * * *$ \\
\hline Single male & 0.042 & $0.014 * * *$ & -0.017 & 0.012 & -0.013 & 0.008 \\
\hline High school graduate & 0.100 & $0.013 * * *$ & 0.093 & $0.012 * * *$ & 0.068 & $0.007 * * *$ \\
\hline College degree or more & 0.199 & $0.015 * * *$ & 0.180 & $0.013 * * *$ & 0.139 & $0.009 * * *$ \\
\hline White & 0.085 & $0.011 * * *$ & 0.071 & $0.011 * * *$ & 0.054 & $0.007 * * *$ \\
\hline Poor health & -0.059 & $0.022 * * *$ & -0.084 & $0.018 * * *$ & -0.063 & $0.012 * * *$ \\
\hline $\begin{array}{l}\text { Willingness to take above average } \\
\text { financial risk }\end{array}$ & 0.107 & $0.009 * * *$ & 0.067 & $0.008 * * *$ & 0.054 & $0.006 * * *$ \\
\hline Investment horizon > 10 yrs & 0.030 & $0.009 * * *$ & 0.044 & $0.009 * * *$ & 0.036 & $0.006 * * *$ \\
\hline $\begin{array}{l}\text { Asks Friends/Relatives/Work } \\
\text { contacts for financial information }\end{array}$ & 0.001 & 0.008 & 0.000 & 0.007 & 0.000 & 0.005 \\
\hline $\begin{array}{l}\text { Uses Internet to obtain financial } \\
\text { information }\end{array}$ & 0.083 & $0.012 * * *$ & 0.054 & $0.011 * * *$ & 0.043 & $0.008 * * *$ \\
\hline Non-investment income & -0.001 & 0.002 & -0.001 & 0.002 & 0.000 & 0.001 \\
\hline Net real wealth & 0.028 & $0.003 * * *$ & 0.009 & $0.002 * * *$ & 0.007 & $0.001 * * *$ \\
\hline Net financial wealth & 0.005 & $0.001 * * *$ & 0.003 & $0.001 * * *$ & 0.003 & $0.000 * * *$ \\
\hline Intention to leave a bequest & 0.083 & $0.009 * * *$ & 0.053 & $0.007 * * *$ & 0.041 & $0.005 * * *$ \\
\hline Has received inheritance & 0.059 & $0.008 * * *$ & 0.051 & $0.008 * * *$ & 0.038 & $0.005 * * *$ \\
\hline Credit constrained & -0.005 & 0.012 & -0.068 & $0.013 * * *$ & -0.050 & $0.009 * * *$ \\
\hline Works/ed in the Financial Sector & 0.052 & $0.009 * * *$ & 0.020 & $0.008 * *$ & 0.016 & $0.006 * * *$ \\
\hline Works in high-risk industry sector & -0.060 & $0.012 * * *$ & -0.014 & 0.014 & -0.012 & 0.010 \\
\hline Has a managerial position & 0.027 & $0.009 * * *$ & 0.036 & $0.009 * * *$ & 0.029 & $0.006 * * *$ \\
\hline Federal marginal tax rate & 0.015 & $0.002 * * *$ & 0.011 & $0.002 * * *$ & 0.009 & $0.001 * * *$ \\
\hline
\end{tabular}

Notes: Pooled data from the 1995, 1998, 2001 and 2004 waves of the SCF. The results for income, net real and non equity financial wealth represent median semi-elasticities, while for the remaining variables average marginal effects. All estimates are corrected for multiple imputation. $* * *, * * *$ denote significance at $1 \%, 5 \%$ and $10 \%$ respectively. Additional regressors include a second degree polynomial in age, a dummy for having children, dummies for employment status, and dummies for years 1998, $2001,2004$. 
Figure 1: Graphical Presentation of the Model

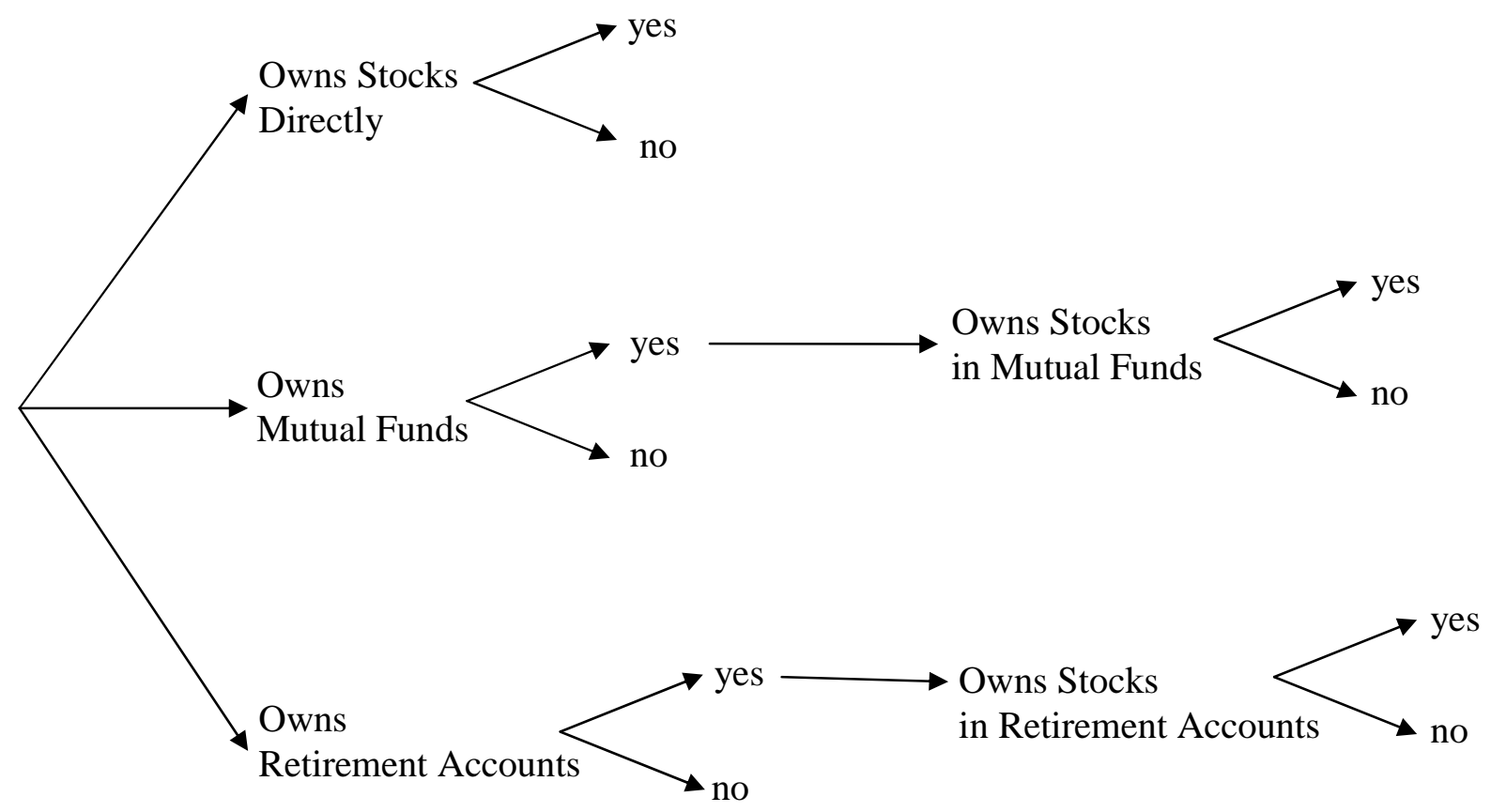




\section{Endnotes}

${ }^{1}$ Interest in stocks as instruments for longer run investing was particularly stimulated by the high realized excess stock returns, especially during the 1990s. The idea that stock return risk diminishes with the length of the investment horizon, however, has been justifiably scrutinized in careful analyses (see Bodie, 1995).

${ }^{2}$ See Campbell (2006), Haliassos and Bertaut (1995), Heaton and Lucas (2000), Gollier (2001), Viceira (2001), Campbell and Viceira (2002), Haliassos and Michaelides (2003), Cocco, Gomes and Maenhout (2005), and Gomes and Michaelides (2005), the contributions in Guiso, Haliassos and Jappelli (2001), Guiso, Haliassos and Jappelli (2003), and Bogan (2008).

${ }^{3}$ The report states that "[t]he growth of equity ownership among America's individual investors during the past 20 years has been fueled largely by the expansion of defined contribution retirement plans, particularly 401(k) plans, which widely use stock mutual funds and other types of mutual funds as investment options. [...] Between 1999 and 2005, the number of households owning equities through employer-sponsored retirement plans grew by 5.2 million. Over the same period, the number of households owning equities outside these plans increased by 2.4 million. [...] Defined contribution retirement plans also play an important role in introducing investors to equity investing and influence investors' initial equity purchases. Today, nearly half of all equity owners began investing in equities by purchasing stock mutual fund shares through retirement plans at work. Among younger equity investors, the proportion is even greater." (p. 2,3)

${ }^{4}$ Examining asset location would not be feasible with other US panel surveys (e.g. the Panel Study of Income Dynamics or the Health and Retirement Study). This is the case because these panel surveys do not distinguish across the three stockholding modes (i.e. direct stocks and stock mutual funds are reported as one asset category); and secondly because every IRA holder is automatically classified as owning stocks through IRAs in view of the fact that the exact fraction invested in stocks is not directly reported (i.e. respondents are asked whether they have mostly invested in stocks/mostly in bonds or split between the two).

${ }^{5}$ For this reason we only report the proportions by pooling all four years together.

${ }^{6}$ Using findings in Carroll and Samwick (1997) we consider Agriculture, Forestry, Fishing, Mining and Construction as high income risk sectors.

${ }^{7}$ Greene uses a multivariate probit with censoring to study default in credit card loans. This model choice is dictated by the fact that defaults are observed only for the selected sample of credit card holders.

${ }^{8}$ We use those authors' equation formulation and notation for our model setup. See also Christelis and Georgarakos (2008), who have used a multivariate probit with selection to study household investment in foreign assets.

${ }^{9}$ The likelihood function is described in further detail in the Technical Appendix.

${ }^{10}$ While our complex econometric model sheds light on various aspects of participation, location, and spillovers, it is not easily extended to analysis of amounts held in stocks. For analysis of the determinants of stockholding amounts, see Bertaut and Starr-McCluer (2001) and Shum and Faig (2006).

${ }^{11}$ Information on some of the covariates we use in our estimation is available only since 1995

${ }^{12}$ Cohort effects cannot be separately estimated from age and time effects, given the linear relationship linking age, time, and cohort. The commonly used assumption of zero cohort effects has been found by Ameriks and Zeldes (2004) to be compatible with most of the observed stockownership patterns in the data. In a recent paper, Malmendier and Nagel (forthcoming) adopt a more flexible specification that takes into account year and age effects as well as life experiences with stock returns that vary not only across but also within a given cohort. They show that those who have experienced low-stock market returns over their lives have a lower probability to invest in stocks.

${ }^{13}$ In addition, coefficients in multivariate probit models are only identified up to scale and show the influence of the regressors on latent variables with no obvious quantitative dimension.

${ }^{14}$ For dummy variables we consider a change from 0 to 1 . For income- and wealth-related continuous variables we present median semi-elasticities (corresponding to a change of 5,000 dollars in 2004 prices). We choose the median since semi-elasticities involve multiplication by the amounts, which are very skewed. Hence the median is to be preferred to the mean in this case. The marginal effect of age is evaluated when age is incremented by one for all household heads, while the marginal effect of the federal marginal tax rate is evaluated when the rate is incremented by five percentage points for all households.

${ }^{15}$ This probability is equal to the sum of the probabilities of all asset combinations in which at least one stockholding mode is chosen.

${ }^{16}$ We find statistically significant positive correlations between unobserved factors influencing participation in direct stockholding and each one of mutual funds, retirement accounts, and stocks in retirement accounts. In addition, unobserved factors influencing participation in stock mutual funds are correlated with those influencing participation in retirement accounts.

${ }^{17}$ Even a high-school certificate makes substantial difference (just under 8 pp). 
${ }^{18} \mathrm{SCF}$ asks explicitly whether a household asks friends or uses the Internet to obtain financial information, allowing for a direct assessment of their contribution on stockholding.

${ }^{19}$ Net financial wealth enters in each equation after deducting the amount of the asset in question in order to avoid endogeneity problems.

${ }^{20}$ We modify the federal marginal tax rate as in Alessie, Hochguertel and Van Soest (2004), in order to avoid endogeneity issues due to dividend income (see Appendix A).

${ }^{21}$ The finding is also consistent with results on the role of education in encouraging gains and avoiding losses in mutual funds in Bilias, Georgarakos, Haliassos (2008).

${ }^{22}$ Van Rooij, Lusardi, and Alessie (2007) show that, in data from the 2005 Household Survey of the Dutch Central Bank (DNB), only about half of the respondents knew that mutual funds are less risky than individual company stocks, and the proportion of incorrect answers was dramatically larger among households of low education.

${ }^{23}$ Roughly $80 \%$ of mutual fund investors also hold stocks in those mutual funds. The figures are analogous for retirement account holders, $80 \%$ of whom hold stocks in them. Estimates for retirement accounts, however, indicate very significant effects of numerous variables in the second stage equation that models stock investment within the accounts (see below).

${ }^{24}$ For example, the relevant probability for stocks in mutual funds is shown in (14).

${ }^{25}$ For example, there is a striking correlation since the early 1990s between the massive spread of retirement account ownership, fueled by government campaigns and tax incentives, and the considerable increase in overall stock market participation, with little movement in the other two candidate modes for stockholding (direct stockholding or in mutual fund ownership). This seems harder to justify as a mere shift in location preferences, but perhaps lends itself more naturally to the interpretation of a policy-induced choice to participate in retirement accounts, accompanied by a decision to include stocks in those long-horizon accounts.

${ }^{26}$ As regards stockholding through retirement accounts we have already seen that there is a distinct second threshold that owners of retirement accounts have to clear. We cannot compare conditional and unconditional marginal effects for stocks in retirement accounts because, by definition, one cannot hold stocks in this form without owning a retirement account.

${ }^{27}$ Indirectly for stock mutual funds, by facilitating investment in mutual funds.

${ }^{28}$ We do not evaluate marginal effects at sample means since this practice can lead to severely misleading results (see Train, 2003, pp. 33-34). 


\section{Discussion Paper Series}

Mannheim Research Institute for the Economics of Aging, Universität Mannheim

To order copies, please direct your request to the author of the title in question.

\begin{tabular}{|c|c|c|c|}
\hline Nr. & Autoren & Titel & Jahr \\
\hline $196-10$ & $\begin{array}{l}\text { Alexander Ludwig, } \\
\text { Thomas Schelkle, } \\
\text { Edgar Vogel }\end{array}$ & $\begin{array}{l}\text { Demographic Change, Human Capital and } \\
\text { Welfare }\end{array}$ & 10 \\
\hline $197-10$ & $\begin{array}{l}\text { Axel Börsch-Supan, } \\
\text { Martin Gasche }\end{array}$ & Zur Sinnhaftigkeit der Riester-Rente & 10 \\
\hline $198-10$ & $\begin{array}{l}\text { Martin Gasche, } \\
\text { Michael Ziegelmeyer }\end{array}$ & $\begin{array}{l}\text { Verbreitung der Riester-Rente - Hat die } \\
\text { Finanz- und Wirtschaftskrise Spuren } \\
\text { hinterlassen? }\end{array}$ & 10 \\
\hline $199-10$ & Martin Gasche & $\begin{array}{l}\text { Rentenanpassung } 2010 \text { - Wem nützt die } \\
\text { Rentengarantie? }\end{array}$ & 10 \\
\hline $200-10$ & $\begin{array}{l}\text { Daniel Kemptner, } \\
\text { Hendrik Jürges, Steffen } \\
\text { Reinhold }\end{array}$ & $\begin{array}{l}\text { Changes in Compulsory Schooling and the } \\
\text { Causal Effect of Education on Health: } \\
\text { Evidence from Germany }\end{array}$ & 10 \\
\hline $201-10$ & $\begin{array}{l}\text { Axel Börsch-Supan, } \\
\text { Martin Gasche }\end{array}$ & $\begin{array}{l}\text { Kann die Riester-Rente die Rentenlücke in } \\
\text { der gesetzlichen Rente schließen? }\end{array}$ & 10 \\
\hline $202-10$ & $\begin{array}{l}\text { Annelies G. Blom, } \\
\text { Edith D. de Leeuw, } \\
\text { Joop J. Hox }\end{array}$ & $\begin{array}{l}\text { Interviewer Effects on Nonresponse } \\
\text { in the European Social Survey }\end{array}$ & 10 \\
\hline $203-10$ & Martin Gasche & $\begin{array}{l}\text { Rentner und Rentnerinnen im deutschen } \\
\text { Sozialversicherungssystem: } \\
\text { Beitragsleistungen und Leistungsbezug }\end{array}$ & 10 \\
\hline $204-10$ & $\begin{array}{l}\text { Dimitris Christelis, } \\
\text { Dimitris Georgarakos, } \\
\text { Michael Haliassos }\end{array}$ & $\begin{array}{l}\text { Differences in Portfolios across Countries: } \\
\text { Economic Environment versus Household } \\
\text { Characteristics }\end{array}$ & 10 \\
\hline $205-10$ & Martin Gasche & $\begin{array}{l}\text { Zusatzbeitrag und sozialer Ausgleich in der } \\
\text { Gesetzlichen Krankenversicherung: } \\
\text { Anreizeffekte und Projektion bis } 2030\end{array}$ & 10 \\
\hline $206-10$ & $\begin{array}{l}\text { Michael Hurd, } \\
\text { Maarten van Rooij, } \\
\text { Joachim Winter }\end{array}$ & $\begin{array}{l}\text { Stock Market Expectations of Dutch } \\
\text { Households }\end{array}$ & 10 \\
\hline $207-10$ & $\begin{array}{l}\text { Michela Coppola, } \\
\text { Christina Benita Wilke }\end{array}$ & $\begin{array}{l}\text { How sensitive are subjective retirement } \\
\text { expectations to increases in the statutory } \\
\text { retirement age? The German case }\end{array}$ & 10 \\
\hline $208-10$ & $\begin{array}{l}\text { Dimitris Christelis, } \\
\text { Dimitris Georgarakos, } \\
\text { Michael Haliassos }\end{array}$ & $\begin{array}{l}\text { Stockholding: } \\
\text { Participation, Location, and Spillovers }\end{array}$ & 10 \\
\hline
\end{tabular}

